\begin{tabular}{c} 
Volume and Issues Obtainable at Center for Sustainability Research and Consultancy \\
Journal of Accounting and Finance in Emerging Economies \\
ISSN: 2519-0318 ISSN (E) 2518-8488 \\
Volume 7: Issue 1 March 2021 \\
CSRC \\
Journal homepage: $\underline{\text { www.publishing.globalcsrc.org/jafee }}$ \\
\hline
\end{tabular}

\title{
A Study of Self-Directed Learning Skills of University Students
}

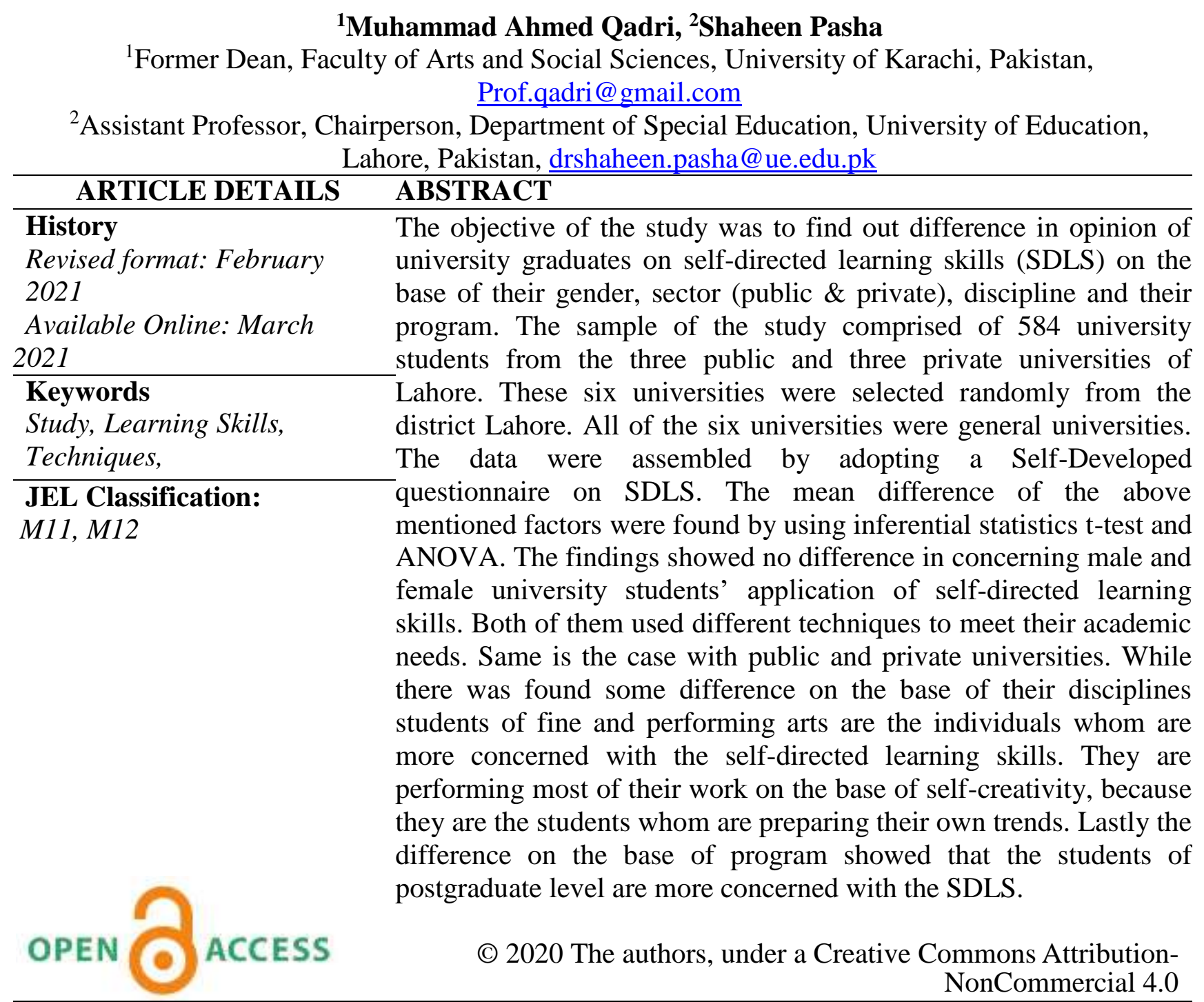

Corresponding author's email address: Prof.qadri@ gmail.com

Recommended citation: Qadri, M. A. \& Pasha, S. (2021). A Study of Self-Directed Learning Skills of University Students. Journal of Accounting and Finance in Emerging Economies, 7(1), 169-176

\section{Introduction}

Attainment of information and getting knowledge has been changed and transformed into new and updated ways. It defied the concept that knowledge is fixed and also introduced new concept that correct and accurate knowledge has been acquired through authorities. Additionally it is also derived that learning is not just memorizing the information it is more than that of knowing and understanding of new concepts and analyze them (Chipamaunga, 2015: Aspin \& Chapman, 2001). So the importance of memorizing the facts has been diminishing from the history of mankind and it has overruled with the concept of leaning into learn to accept the change. A person who can learn has derive his own meaning 
and transfer it to a new information into a wider context, solve his problems by hands on activities and he is independent in development and change. A person who can develop his own understanding may possess more self-confidence in his awareness and knowledge. He is more willing to learn and use various strategies to learn new things he may show more interest in his learning and create his own values which will help him to be more authentic and confident in his views (Rawson, 2000; Council, 2000; Tekkol \& Demirel,. 2018; Fredriksson \& Hoskins, 2007; Hofmann, 2008).

Self-directed learning makes a person independent in his learning and make an attempt to be aware of his own interests and curiosities. Simultaneously, person is creating his own values, so he can comprehend the basics of knowledge not only memorize it. Self-directed learning helps people who want to develop themselves or get further education to meet their learning requirements without any restriction and amenably. So consequently SDL needs of the individuals can be achieved formally and informally in both of the terms (Aspin \& Chapman, 2001).

Self-directed learning considers continuity among initial gaining experience and professional cycle necessary. Adult education is related to it. So, it may not be restricted to a specific age limit (Mocker \& Spear, 1982). It focuses on the information and abilities that are needed by everyone, without considering any age limits. Past studies suggests that lifetime learning includes 20th century knowledge, and that competencies may considered to essential addition in the knowledge community. Self-study is one of these skills. Past researches reveal a strong connection among constructive period and behavior. Greveson and Spencer (2005) supported that SDL is essential for long term learning, on the other hand Candy (1990) stresses that there is a mutual link exist between of the both terms.

Candy (1990) concluded, SDL helps people to learn the facts and make it permanent on their memory. This helps them learn skills that they can work on and are able to learn in real life (Blaschke, 2012). Based on this belief, self-reflection means ultimately lifetime acquisition of knowledge (Candy, 1990). Mocker and Spear (1982), emphasized that independent education is part of lifelong learning and makes learning more orderly and understandable. According to Dunlap and Grabinger (2003) self-instruction prepares people for lifelong learning. Giusto and DiBiosio (2006) stated that behavior should include lifelong learning understanding. As such, SDL and lifetime learning are correlated with each other and based upon one another.

It is also known that self-discipline, self-study and its great understanding are that people are now able to start working to see what they need to improve their competencies, their ability in selecting/using accurate learning methods or to measure the value of learning by getting help by oneself or on their own (Knowles, 1975). Self-study, the process by which people take the first steps in planning, continuing, and evaluating their learning experience (Mary \& others, 2007). In self-study, the learning process is transferred from one source (as a teacher) to another. In this way, it is important to manage students and actively participate in the learning process (Boyer \& Usinger, 2015; Grover, 2015).

Independent gaining of knowledge involves the understanding, design, application, and assessment of student-led acquiring of knowledge (Brookfield, 2009). It is also sometimes referred to as a way for students to organize their learning tasks. In addition, self-learning can be seen as a goal that students want to achieve. To achieve this, individuals are responsible for their learning, accepting their autonomy and inclination (Kauffman, 2003). Individuals teach students to set clear goals, improve their academic process with goals and objectives, evaluate their academic process, measure their own learning outcomes, independent, passionate, open to learning, curious, ready to learn, educational outcomes, selfmanagement, learning initiative (Knowles, 1977; Jennett, 1992; Tatlah,2015; Boyer, Edmondson, Artis, \& Fleming, 2014). Self-education promotes self-esteem, independence, support and lifelong learning (O'Shea, 2003), however, self-education needs more opportunities. It helps the learners to become active participants and assist in learning lifelong skills (Spencer \& Jordan, 1999). Hence, a number of 
competencies are required while developing self-directed learning.

Self-examination shows that there are many ways to define it. Fewer researches denote it as self-study, others define it learn by self or self-regulated learning methods or learn by their own. Many of the details of your own learning have been seen in students. Fewer students in the world have high schools and motivated too. Mutually explanatory and empirical researches were completed. Their design is versatile and largely based on quantitative studies has a high level of performance. Additionally, Guglielmino's "Self-Directed Learning Readiness Scale" project recommended via fewer investigators. Additionally, some of the scales developed by the scholars/ investigators. These scales typically focus on the presentation of disciplines and programs of students or educational materials (research scores, faculty, assessment tools, etc.), and have not the factors related to students' universal SDLS.

Much work in the global literature on SDLS, and much scale development research accompanied to measure SD observational competencies (Guglilmeno, 1977; Fisher \& Tague, 2001; Hendry \& Gins, 2009; Stockdale \& Brockett, 2011; Shen, Chen, \& Hu, 2014; Cadorin, Bressan, \& Palese, 2017). Few of the researches conducted on the suggested models for the self-improvement of graduates (Aly, Willems, Carels \& Elen, 2003; Tatlah,2014; Sawatsky, Ratelle, Bonnes, Egginton \& Beckman, 2017). Majority of the respondents of in these researches were understudies.

The outcomes of past research show that self-learning involves high-level competencies such as creativeness, problem solving and reasoning. Additionally, some research shows that academic achievement is closely linked to independent learning. As for gender variables, some studies did not have a significant effect among both genders. Further results show, graduates who want to continue their undergraduate studies have more potential for independent learning.

\section{Purpose and Importance}

The study objective was to ascertain differences among students' ability to learn independently, depending on gender, sector (public and private) students, discipline and program. The variables are intent on the outcomes of past studies on the matters i.e. self-regulated learning, learning approaches etc. Self-learner students predefine their clear goals, who perform according to the plan, who act proactively, who are vulnerable to learning, motivated, confident, and autonomous. In the fast-paced world of information, these traits are sought after by modern people. After all, anyone who manages learning can learn to get information and think at an advanced level.

In short, they learned to learn. Having these behaviors will give students a sense of self -worth and energy after graduation, they will be motivated to learn, they will have access to academic education when they love to learn; In short, they went to do their full school. Hence, it is essential to find out university graduates' SDLS. Concerns are below on the base of which current study was conducted:

- Is there any noteworthy variance amid public and private University students' SDLS on the base of gender?

- Is there any noteworthy difference amid public and private University students' SDLS?

- Do University students' SDLS have any significance difference on the base of discipline?

- Do University students' SDLS varies notably on the base of their program?

\section{Limitations}

This study is limited to;

Three public and three private Universities of Lahore

All the six universities are general universities

\section{Research Design}

Current study aims in finding the variance of university students' SDLS on the base of university 
students' gender, sector, discipline and program. Simply defined, university graduates' SDLS were examined on the base of their demographics. Consequently, the survey method was deployed in this study (descriptive method).

\subsection{Sample}

The research was accompanied at six universities in district Lahore. Three public and three private sector universities were selected. The purpose was to deduce the noteworthy variance amid the male and female, public and private, different disciplines and programs of with regard to SDLS. These universities were selected randomly. The sample of the study comprised of 584 university students from different departments of the six selected universities from the district Lahore.

\subsection{Data Collection}

Data were assembled by deployed self-developed questionnaire. The demographic information included questions about students' gender, university type, discipline and program. Researchers gathered the data from the students whom were studying in these six randomly selected universities personally. Permission was obtained by the department of these universities to collect the data through selfdeveloped questionnaire. Written consent was collected by the researcher from all the participants before conducting this survey.

\section{Data Analysis}

The number of the participants were 600 , but the correctly filled questionnaire were 584 . So the incomplete and not filled properly form were excluded from the total number of distributed forms. After collecting the properly filled forms, data were analyzed on SPSS. Descriptive statistics, $t$-test and one way analysis of variance (ANOVA) were employed by the researcher.

Table 1: t-test for mean difference on the basis of gender

\begin{tabular}{|c|c|c|c|c|c|c|c|}
\hline & Gender & $\mathrm{N}$ & Mean & $\begin{array}{l}\text { Std. } \\
\text { Dev. }\end{array}$ & $\frac{\frac{\mathrm{t} \text {-test }}{(\alpha=0.05)}}{d f}$ & $\mathrm{t}$ & Sig. \\
\hline Self-directed & Male & 238 & 2.71 & .419 & 582 & -.044 & .965 \\
\hline learning skills & Female & 346 & 2.71 & .405 & & & \\
\hline
\end{tabular}

The table 1 shows t-test was run to find the mean score difference amid both genders of university graduates. The noteworthy score shows no variation midst the views of male and female graduates. All of the male and female university students apply SDLS in their studies.

Table 2: t-test for mean difference on the basis of University Sector (public and private)

\begin{tabular}{llllllll}
\hline & Sector & $\mathrm{N}$ & Mean & Std. Dev. & $\frac{\mathrm{t} \text {-test }}{(\alpha=0.05)}$ & & \\
& & & & & $\frac{2}{d f}$ & $\mathrm{t}$ & Sig. \\
\hline Self-directed & Public & 286 & 2.71 & .418 & 582 & -.018 & .986 \\
learning skills & Private & 298 & 2.71 & .404 & & & \\
\hline
\end{tabular}

Table no 2 shows that the mean values of public and private university students are not at the significant difference. Both of the sectors' (public and private) university graduates applied SDLS in their studies. 
Table 3: One way ANOVA on different Disciplines of University Students

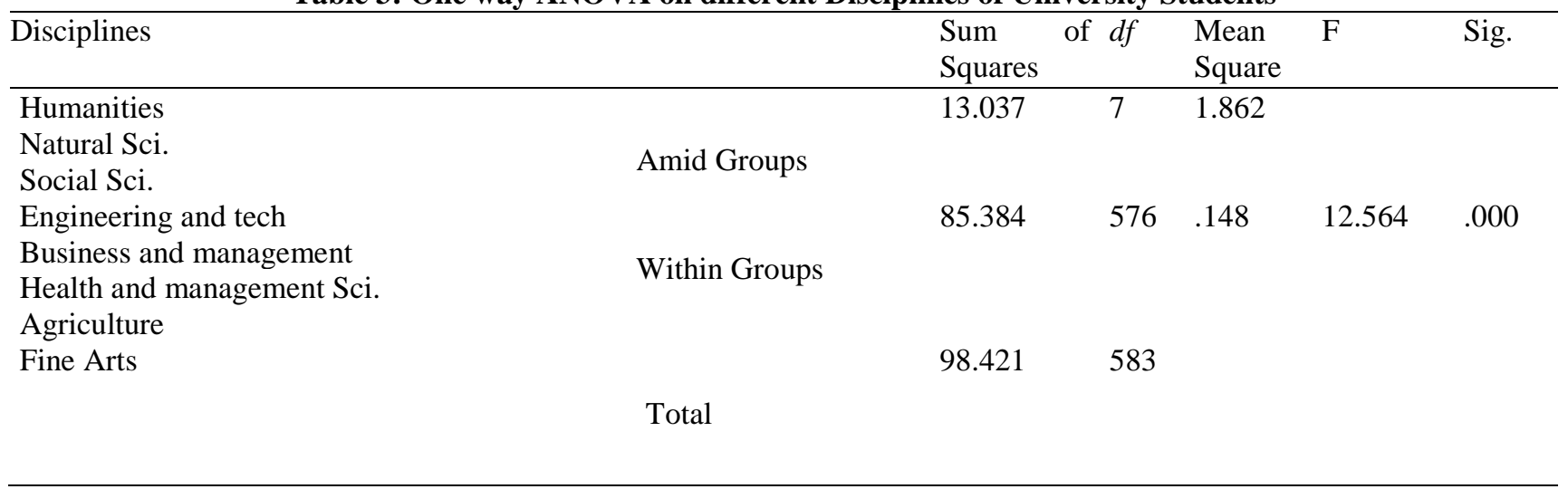

Table 3 shows that significant difference was found in applying the SDLS in the studies of graduates with respect to their discipline $(\mathrm{F}=12.564)$ at $p<0.05$. Students of Health and management sciences and Fine and Performing Art are the disciplines whom students are more inclined towards the selfdirected learning.

Table 4: One way ANOVA on different Programs of University Students

\begin{tabular}{lllllll}
\hline Programs & & Sum of Squares & $d f$ & Mean Square & F & Sig. \\
\hline BS Hons & Between Groups & 2.018 & 3 & .673 & 4.047 & .007 \\
$\begin{array}{l}\text { Masters MS/MPhil } \\
\text { PhD }\end{array}$ & & & & & \\
& Within Groups & 96.403 & 580 & .166 & & \\
\hline & Total & 98.421 & 583 & & & \\
\hline
\end{tabular}

Table no 4 revealed significance dissimilarity among groups of various programs of university graduates with reference to self-directed learning skills as the value represents $(\mathrm{F}=4.047), \mathrm{p}<0.05$. The students of PhD program are more inclined regarding the SDLS. By way of the mean value of PhD students represents.

\section{Conclusion and Discussion}

Current study aimed at examining the difference in the opinion of university graduates SDLS on the base of gender (male and female), sector (Public and private), Discipline and Program (BS Hons., Masters, MS/MPhil and $\mathrm{PhD}$ ). The results showed that both male and female university graduates apply these skills in their studies. The results shows that university students are self-struggling individuals and they prefer learning by themselves and very open to learn by their own (Oddi, 1984). Researches on SDLS concluded that "guilelessness" is an essential feature associated with SDL (Cazan \& Schiopca, 2014). On the contrary literature concluded that female show higher SDLS as compare to males (Guglielmino, Guglielmino, \& Long, 1987; Demirtas \& Ozer,. 2007; Hutto, 2009; Slater, Cusick \& Louie 2017; Swart, 2018). It may therefore be assumed that students of both genders are ready to learn. University students monitor their own learning both of the public and private university students. They monitor their learning and apply self-directed leaning in their studies (Knowles, 1975) it is therefore, they monitor their learning on the base of their needs to achieve their set goals, to estimate the erroneous or underprovided learning and apply new ways in their learning. The results of public and private university students revealed that there is no difference significance dissimilarity in the application of SDLS concerning both sectors students. Both of the students either public university or private prefer to learn on their own and want to advance in their subject matter. Turner (2007) with different high school learners found, their SDL willingness intensities was not vary notably.

While considering the Students disciplines it was concluded that the students of Health and management sciences and Fine and Performing Arts are preferably join SDLS. They considered students of practical work. Fine arts is a subject where students has the need to self-direct their work and to do something 
creative. While analyzing the scores of university graduates on their SDLS, regarding their discipline, least scores related to agriculture and Natural Sciences. Further tracked by Health and Social Sci. graduates. Fine and performing arts is the discipline which showed a higher score the performing the SDLS. Hence it found that university graduates SDLS are notably different on the base of their discipline. It was observed that Fine Arts, Social and Health Sciences graduates were meaningfully advanced SDLS as compare to Natural Sci. graduates. If considering the scores on the base of discipline it was derived that Fine Arts is the subject which is highly scored and proved that these students applied self-directed learning skills in their studies as it is required by their subject. The students of Fine Arts are the most creative students as it is the need of the discipline. San (1983) concluded that it is the objective of the Fine Arts studies "prepare the people whom would be creative and open in all field of life. The purpose of the Fine Arts is to develop an individual as a productive and independent learner, whom involved in creativity without any restriction of mental abilities. So the individuals of Fine Arts are naturally creative and entrepreneurial. Aral (1999) also established in his studies that Fine Arts graduates significantly higher in their creativity as compare to other disciplines. Past studies also commenced a strong relativity amongst SDLS and creativity (Guglielmino, Guglielmino, \& Long, 1987; Edmondson, Boyer, \& Artis, 2012; Yaman, 2014). The students of Fine Arts and Social Sci. mostly learn by their own because of the nature of their subjects, so this practice makes them more self-dimensioned learners, enhance their qualities in learning the things more accurately as compare to natural sciences.

SDL is most of the time considered as adult edification, it is also the ability to make oneself independent in making their decisions according to their prerequisites and capability to align learning in accordance to their aims. So the postgraduate students of university programs are the mostly self-directed learners who applied self-directed learning skills in their studies as they are more motivated and clear about their work. It may be of their maturity level or either they are much more aware of their goals in their near future. Some of the past studies support this result (Edmondson, Boyer, \& Artis, 2012; Cook, et al., 2017; Swart, 2018).

\section{Recommendations}

1. It would be more useful if this study conducted on a mix-method approach.

2. The results of the students must also be included so that their performance will also be checked and it would make clear either SDLS have progressive influence on learning.

\section{References}

Aly, M., Willems, G., Carels, C., \& Elen, J. (2003). Instructional multimedia programs for self-directed learning in undergraduate and postgraduate training in orthodontics. European Journal of Dental Education, 7(1), 20-26.

Aral, N. (1999). Sanat egitimi-yaratıcılık etkilesimi. Hacettepe Universitesi Egitim Fakultesi Dergisi, 15(15), 11-17.

Aspin, D., \& Chapman, J. (2001). Towards a philosophy of lifelong learning. In International handbook of lifelong learning (pp. 3-33). Springer, Dordrecht.

Beach, P. (2017). Self-directed online learning: A theoretical model for understanding elementary teachers' online learning experiences. Teaching and Teacher Education, 61, 60-72.

Blaschke, L. M. (2012). Heutagogy and lifelong learning: A review of heutagogical practice and self-determined learning. The International Review of Research in Open and Distributed Learning, 13(1), 56-71.

Boyer, S. L., Edmondson, D. R., Artis, A. B., \& Fleming, D. (2014). Self-directed learning: A tool for lifelong learning. Journal of Marketing Education, 36(1), 20-32.

Boyer, N. R., \& Usinger, P. (2015). Tracking pathways to success: triangulating learning success factors. International Journal of Self-Directed Learning, 12(2), 22-48.

Brookfield, S. D. (2009). Self-directed learning. In International handbook of education for the changing world of work (pp. 2615-2627). Springer, Dordrecht.

Cadorin, L., Bressan, V., \& Palese, A. (2017). Instruments evaluating the self-directed learning 
abilities among nursing students and nurses: a systematic review of psychometric properties. BMC medical education, 17(1), 1-13.

Candy, P. C. (1990). The transition from learner-control to autodidaxy: More than meets the eye. Advances in research and practice in self-directed learning, 9-46.

Cazan, A. M., \& Schiopca, B. A. (2014). Self-directed learning, personality traits and academic achievement. Procedia-Social and Behavioral Sciences, 127, 640-644.

Chipamaunga, S. R. (2015). How students develop the ability to integrate learning-a phenomenographic study (Doctoral dissertation, University of the Witwatersrand Johannesburg).

Cook, D. A., Blachman, M. J., Price, D. W., West, C. P., Berger, R. A., \& Wittich, C. M. (2017). Professional development perceptions and practices among US physicians: a cross-specialty national survey. Academic Medicine, 92(9), 1335-1345.

Council, N. (2000). How people learn: Brain, mind, experience, and school: Expanded edition. Washington, D.C.: National Academies Press.

Demirtaş, H., \& Ozer, N. (2007). Öğretmen adaylarının zaman yonetimi becerileri ile akademik basarısı arasındaki iliskisi. Egitimde Politika Analizleri ve Stratejik Araştırmalar Dergisi, 2(1), 34-47.

Dunlap, J. C., \& Grabinger, S. (2003). Preparing students for lifelong learning: A review of instructional features and teaching methodologies. Performance Improvement Quarterly, 16(2), 6-25.

Edmondson, D. R., Boyer, S. L., \& Artis, A. B. (2012). Self-directed learning: A meta-analytic review of adult learning constructs. International Journal of Education Research, 7(1), 40-48.

Fisher, M., King, J., \& Tague, G. (2001). Development of a self-directed learning readiness scale for nursing education. Nurse education today, 21(7), 516-525.

Fredriksson, U., \& Hoskins, B. (2007). The development of learning to learn in a European context. The Curriculum Journal, 18(2), 127-134.

Tekkol, İ. A., \& Demirel, M. (2018). An investigation of self-directed learning skills of undergraduate students. Frontiers in psychology, 9, 2324.

Greveson, G. C., \& Spencer, J. A. (2005). Self-directed learning--the importance of concepts and contexts. Medical education, 39(4), 348-349.

Grover, K. (2015). Online social networks and the self-directed learning experience during a health crisis. International Journal of Self-Directed Learning, 12(1), 1-15.

Guglielmino, L. (1977). Development of the Self-Directed Learning Readiness Scale, (unpublished doctoral dissertation), University of Microfilm International. Ann Arbor, Michigan.

Guglielmino, P. J., Guglielmino, L. M., \& Long, H. B. (1987). Self-directed learning readiness and performance in the workplace. Higher Education, 16(3), 303-317.

Haggerty, D. L. (2000). Engaging adult learners in self-directed learning and its impact on learning styles (Doctoral dissertation, University of New Orleans).

Hendry, G. D., \& Ginns, P. (2009). Readiness for self-directed learning: validation of a new scale with medical students. Medical teacher, 31(10), 918-920. 173-181.

Hofmann, P. (2008). Learning to learn: a key-competence for all adults? Convergence, 41(2),

Hutto, S. T. (2009). The relationships of learning style balance and learning dimensions to selfdirected learning propensity among adult learners, (unpublished doctor of philosophy thesis). The University of Southern Mississippi, Mississippi.

Jennett, P. A. (1992). Self-directed learning: A pragmatic view. Journal of Continuing Education in the Health Professions, 12(2), 99-104.

Jiusto, S., \& DiBiasio, D. (2006). Experiential Learning Environments: Do They Prepare Our Students to be Self-Directed, Life-Long Learners? Journal of Engineering Education, 95(3), 195-204.

Kaufman, D. M. (2003). Applying educational theory in practice. Bmj, 326(7382), 213-216.

Knowles, M. S. (1975). Self-directed learning: A guide for learners and teachers, Cambridge: Englewood Cliffs.

Lopes, J. B., \& Cunha, A. E. (2017). Self-directed professional development to improve effective teaching: Key points for a model. Teaching and Teacher Education, 68, 262-274. 
Mamary, E., \& Charles, P. (2003). Promoting self-directed learning for continuing medical education. Medical teacher, 25(2), 188-190.

Merriam, S. B., Caffarella, R. S., \& Baumgartner, L. M. Learning in Adulthood: A Comprehensive Guide, (San Francisco, CA: John Wiley \& Sons/Jossey-Bass, 2007. Reflective Practice: Formation and Supervision in Ministry, 31.

Mocker, D. W., \& Spear, G. E. (1982). Lifelong learning: Formal, nonformal, informal, and selfdirected. Columbus, OH: ERIC Clearinghouse on Adult, Career, and Vocational Education.

Oddi, L. F. (1984). Department of an instrument to measure self-directed continuing learning. (Unpublished Doctor of Education Thesis). Northern Illinois University, Illinois.

Organisation for Economic Co-operation and Development. (1996). Lifelong learning for all: meeting of the Education Committee at Ministerial level, 16-17 January 1996. Paris: OECD.

O'Shea, E. (2003). Self-directed learning in nurse education: a review of the literature. Journal of advanced nursing, 43(1), 62-70.

Rawson, M. (2000). Learning to learn: more than a skill set. Studies in Higher Education, 25(2), 225-238.

San, I. (1983). Sanat Egitimi Kuramlari [Theories of Art Education]. Ankara: Tan.

Sawatsky, A. P., Ratelle, J. T., Bonnes, S. L., Egginton, J. S., \& Beckman, T. J. (2017). A model of self-directed learning in internal medicine residency: a qualitative study using grounded theory. $B M C$ medical education, 17(1), 1-9.

Shen, W. Q., Chen, H. L., \& Hu, Y. (2014). The validity and reliability of the self-directed learning instrument (SDLI) in mainland Chinese nursing students. BMC medical education, 14(1), 1-7.

Slater, C. E., Cusick, A., \& Louie, J. C. (2017). Explaining variance in self-directed learning readiness of first year students in health professional programs. BMC medical education, 17(1), 1-10.

Spencer, J. A., \& Jordan, R. K. (1999). Learner centred approaches in medical education. Bmj, 318(7193), 1280-1283.

Stockdale, S. L., \& Brockett, R. G. (2011). Development of the PRO-SDLS: A measure of selfdirection in learning based on the personal responsibility orientation model. Adult Education Quarterly, 61(2), 161-180.

Swart, A. J. (2018). Self-directed learning - fashionable among all first-year African engineering students? Global Journal of Engineering Education, 20 (1), 15-22.

Tatlah, I. A. (2015). Effect of leadership behaviour and school organizational health on students'achievement. Lahore: (Unpublished Doctoral Thesis) University of Management and Technology, Lahore.

Tatlah, I. A., Iqbal, M. Z., Amin, M., \& Quraishi, U. Q. (2014). Effect of leadership behaviour of principals on students' academic achievement at secondary level: A comparison of leaders and teachers perceptions. Journal of Research and Reflections in Education, 1-12.

Turner, J. E. (2007). Readiness for Self-Directed Learning: Comparison of College-Prep and Vocational Education Public High School Seniors. (Unpublished Doctor of Philosophy Thesis). University of Missouri, St. Louis.

Williamson, S. N. (2007). Development of a self-rating scale of self-directed learning. Nurse researcher, 14(2).

Yaman, F. (2014). Investigating of lifelong learning tendency of teachers (The example of Diyarbakir. (Unpublished master's thesis). Dicle University, Diyarbakir, Turkey. 